\title{
Alusão ao nazismo em mensagem do governo federal: um estudo a partir da economia dos sinais e da ecologia da comunicação
}

\author{
Allusion to nazism in a message from the federal \\ government: a study based on sign's economy and \\ communication's ecology
}

\author{
Agnes de Sousa Arruda a,* \\ Tadeu Rodrigues luama a
}

\begin{abstract}
RESUMO: A comunicação do atual governo federal brasileiro faz uso de estratégias de emissão massiva e das tecnologias digitais que proporcionam o compartilhamento em rede. Falas excludentes se tornaram frequentes, sendo emblemática a publicação de um vídeo cujo discurso foi emulado do ministro da propaganda da Alemanha Nazista, Joseph Goebbels. O episódio culminou na demissão do secretário responsável pela pasta que veiculou a mensagem, mas não encerrou o modelo de comunicação utilizado. Apresenta-se uma interpretação de tal estratégia de comunicação à luz da economia dos sinais, conforme Harry Pross. A partir de um estudo de caso, traça-se um prognóstico para a troca de mensagens em seu uso social, alicerçado pela ecologia da comunicação, proposta por Vicente Romano: um contraponto ético em processos comunicacionais, lastreado nas relações sociais celebrantes da diversidade.
\end{abstract}

Palavras-chave: Ecologia da Comunicação; Economia dos sinais; Política brasileira.

ABSTRACT: The communication of the current Brazilian federal government makes use of massive broadcasting strategies and digital technologies that provide network sharing. Excluding speeches became frequent, and the publication of a video whose speech was emulated from Nazi Germany's propaganda minister, Joseph Goebbels, is emblematic. The episode culminated in the dismissal of the secretary responsible for the department, but it did not end the communication model used. An interpretation of such a communication strategy is presented in the light of the signal economy, according to Harry Pross. Based on a case study, a prognosis for the exchange of messages in their social use is outlined, based on the ecology of communication, proposed by Vicente Romano: an ethical counterpoint in communication processes, based on the social relationships that celebrate diversity.

Keywords: Communication ecology; Signal economy; Brazilian politics.

a Programa de Pós-Graduação em Comunicação e Cultura, Universidade de Sorocaba, Sorocaba, SP Brasil.

*Correspondência para/Correspondence to: Agnes de Sousa Arruda. E-mail: agnesarruda@gmail.com.

Recebido em/Received: 22/02/2021; Aprovado em/Approved: 14/05/2021.

Artigo publicado em acesso aberto sob licença CC BY 4.0 Internacional ()(i) 


\section{INTRODUÇÃO}

A garantia em Constituição de uma imprensa livre muitas vezes se confunde com outro direito constitucional: o da liberdade de expressão. Foi com essa premissa, inclusive, que em 2009 o Supremo Tribunal Federal - STF deliberou pela não obrigatoriedade do diploma para a atuação jornalística profissional. Enquanto as discussões técnicas e acadêmicas em relação a essas questões giram em torno da atualização das diretrizes curriculares para o curso de jornalismo ou a (falta de) qualidade das produções jornalísticas pós-queda da exigência da formação, floresce vertiginosamente a propagação de preconceitos, negacionismos e ideais fascistas disfarçados de liberdade de expressão, relacionados às atualizações contemporâneas de fenômenos arcaicos de desinformação, tais como a falácia e o ostracismo; e é sobre esse argumento que se desenvolve este trabalho, desenvolvido a partir de estudo de caso (Duarte 2010), em sua perspectiva qualitativa, que considera o fenômeno contextualizado na contemporaneidade.

Para isso, recorre-se ao cenário político brasileiro atual, que pouco contribui para um diálogo minimamente sério nesse sentido. Quando o senso comum é elevado ao status de lei, atitudes como a do Presidente da República, ao ameaçar o fechamento e cancelar a assinatura no governo federal de um dos jornais de maior circulação no país por não gostar da abordagem que o veículo faz em suas coberturas, geralmente denunciando abusos e irregularidades em suas ações, tornam-se corriqueiras e reverberam entre seus seguidores (Folha 2019). Assim como ofensas públicas nas quais o Presidente afirma que produtos comprados com o cartão corporativo do poder executivo, superfaturados, são para "enfiar no rabo da imprensa" (Uol 2021). Soma-se a isso o fenômeno da autopublicação, para além do que esse termo significa no mercado editorial. Em seus próprios canais em meios sociais digitais como o Twitter, o Facebook e o Instagram, por exemplo, o presidente e aqueles que o cercam proliferam toda uma sorte de declarações controversas.

De "menino veste azul menina veste rosa", dito pela ministra da Mulher, Família e Direitos Humanos (Pains 2019), passando por "fazer cocô dia sim, dia não", como uma solução para os problemas ambientais (G1 Brasília 2019) e "falar que se passa fome no Brasil é uma grande mentira", porque segundo o presidente não se vê nas ruas pessoas pobres em forma "esquelética" (Cople 2019), a proliferação deliberada de informações falsas comparece cotidianamente. Isso ainda sem considerar as atrocidades na gestão da crise de saúde pública provocada pela pandemia de SARS-CoV-2, iniciada no primeiro semestre de 2020 e que fizeram o presidente ser denunciado no tribunal de Haia por crimes contra a humanidade (Cruz 2020).

Um levantamento da agência de checagem Aos Fatos no começo de 2019 apontou que apenas nas primeiras dez semanas de governo o presidente havia dado, em média, uma declaração falsa por dia. Foram 149 declarações, das quais “[...] 67 apresentavam informações verdadeiras, 52 tinham algum grau de erro e outras 30 continham dados completamente falsos" (Nalon; Cunha; Libório 2019). Nesse cenário, torna-se atrativo contestar a credibilidade da imprensa com o respaldo da ausência de profissionalismo 
em suas atividades e, assim, nomear outros meios como dignos de confiança. O aplicativo de mensagens instantâneas WhatsApp é um deles. Em outubro do ano passado, a própria empresa admitiu que houve o envio maciço ilegal de mensagens em suas contas, e que esse envio pode ter interferido no resultado do pleito de 2018 (Mello 2019). Os gritos de “WhatsApp! WhatsApp!”, proferidos por apoiadores do presidente em sua posse a um repórter da Globo (Maia 2019), ilustram a especulação.

As informações falsas e as declarações polêmicas do presidente e de seus ministros, secretários e assessores reverberam amplamente entre a população - a critério de exemplo da afirmação, nota-se a relação entre, no contexto da pandemia de SARS-CoV2, a queda de tuítes anti-vacinação após adoção de fala pró-vacina de Bolsonaro (Oliveira 2021). No entanto, há comunicações que não são verbalmente explícitas, mas nos símbolos que evocam aquilo que de pior a história recente da humanidade foi capaz de produzir e vivenciar. É o caso do vídeo que foi ao ar na página oficial da Secretaria Especial da Cultura do Governo Federal na noite de 16 de janeiro de 2020.

Trata-se de uma comunicação oficial do Governo Federal, uma vez que publicada na conta em rede social registrada em nome da Secretaria Especial de Cultura. Da mesma forma que seu protagonista, o então secretário da Pasta, Roberto Alvim, ao se comunicar por um canal oficial, é tratado como um representante do governo. Isso porque, conforme apontam Duarte e Fonseca Júnior (2003, p. 329-330), "um ministro responde pelo Ministério, pelo Governo; um diretor, ao falar para a TV, simboliza a organização que atua. E um porteiro, mesmo que não fale oficialmente, transmite a ideia do comportamento, da cultura da instituição em que atua".

No vídeo, o então secretário, ao divulgar o Prêmio Nacional das Artes, lançado momentos antes em transmissão ao vivo também nas redes sociais pelo Presidente da República, utiliza estética visual e trilha sonora similares às utilizadas em propagandas nazistas. Ao parafrasear Joseph Goebbels, ministro da propaganda de Adolf Hitler, as intenções de Alvim não passaram despercebidas e repercutiram de forma negativa nacional e internacionalmente (Folha 2020). A situação se tornou insustentável para o governo, o que levou Alvim à exoneração no dia seguinte à postagem do vídeo (Nikklas; Guimarães 2020).

Essa foi a primeira demissão do governo por conta de um discurso declaradamente nazifascista, entre tantos outros proferidos até mesmo pelo próprio presidente (Fonseca 2019). Assim, por entender a importância dos processos narrativos e imagéticos, em especial aqueles que se passam na internet, na sociedade contemporânea, este trabalho foca em não só apresentar e analisar os signos recorrentes no vídeo e a que eles evocam, como também compreender seus motivos de impacto a partir dos conceitos de simulacro (Morin 2002), economia dos sinais (Pross 1997) e mimese na cultura (Gebauer; Wulf 2004) para, a partir daí, refletir acerca da ecologia da comunicação (Romano, 2004; Menezes 2016) como contraponto que visa o aumento do potencial democrática da comunicação em um contexto de conservadorismo extremo como o que desponta. 
Problematiza-se neste estudo o uso de elementos que fazem referência ao neofascismo, bem como sua possível intencionalidade e aderência junto à sociedade, levantando a hipótese de que, no contexto brasileiro, embora a referência seja percebida, tais elementos não condizem com a realidade de uma população diversa e miscigenada. Além disso, questiona-se a relação técno-econômica presente, em uma situação na qual a transmissão wébica/de massa atende à mesma lógica sistêmica do capital, enquanto como alternativa reparadora, sustentável e vinculadora dos processos de comunicação se apresenta a teoria Romano (2004) para a qual se faz fundamental a mimese.

\section{OS SÍMBOLOS VIVEM MAIS QUE OS HOMENS}

O comunicólogo Harry Pross alertou para a sobrevida dos símbolos em relação aos seus criadores; pensamento sintetizado na frase "os símbolos vivem mais longamente que homens" (Pross apud' Baitello Junior 1999, p. 104). Ao possuírem essa longevidade sobre-humana, acabam se tornando materializações de ideologias, estas compreendidas, em um primeiro momento, como "[...] um conjunto de idéias e de valores respeitantes à ordem pública e tendo como função orientar os comportamentos políticos coletivos" (Bobbio; Matteucci; Pasquino 1998, p. 584) e, em uma segunda perspectiva, com origem no pensamento marxiano, "[...] como falsa consciência das relações de domínio entre as classes [...]" (idem). Independente do significado, ambas operam por mecanismos similares a partir das convenções sociais acerca daquilo que representam para o grupo.

Nesse sentido, busca-se por uma interpretação possível do vídeo veiculado por Alvim (Secretário 2020). Os elementos presentes no vídeo no plano audiovisual e no plano da narrativa serão desenrolados a partir de seus contextos históricos, políticos e sociais, em busca de um detalhamento técnico dos argumentos de comunicação utilizados. Isso porque, no estudo de caso, método empenhado neste artigo, pode-se considerar não só o movimento exploratório em relação ao objeto, como também a descrição de sua complexidade (Bruyne; Herman; Schoutheete apud Duarte 2010), tendo como características o particularismo do objeto, sua descrição, sua explicação e a indução possível a partir do mesmo (Merrier apud Duarte 2010). Dessa forma faz-se necessário elencar, além da contextualização, os campos de interação, instituições e estruturas sociais envolvidas e meios técnicos de transmissão, com o objetivo de se propor uma interpretação que, embora não vise esgotar o assunto, se mostre consistente, traçando um prognóstico para a troca de mensagens em seu uso social, lastreado nas relações sociais celebrantes da diversidade.

Assim, no cenário posto, além do protagonista do vídeo, temos a bandeira brasileira à sua direita, uma cruz de Caravaca à esquerda e uma imagem de Jair Bolsonaro,

\footnotetext{
${ }^{1}$ A obra de Harry Pross é inacessível em língua portuguesa. Seu pensamento, contudo, alcança o Brasil principalmente por meio de Norval Baitello Junior, que entrou em contato com Pross durante seu doutoramento na Universidade Livre de Berlim, na década de 1980, e que facilita assim o acesso para o desenvolvimento deste artigo.
} 
presidente do Brasil na ocasião. Como trilha sonora, ouve-se a ópera Lohengrin, de Richard Wagner. A presença da bandeira evoca o nacionalismo; a cruz de Caravaca (também conhecida como cruz de Lorena e cruz de Borgonha), por sua vez, é um símbolo jesuíta. Ao ser associada ao conteúdo verbalizado, pode-se apontar para um reforço do caráter proselitista que dá o tom ao pronunciamento. A própria ideia de Cruzada, no sentido literal de guerra santa que visa a expansão e o domínio cristão, nos parece alinhada com o uso da expressão Deus Vult (Deus quer, em latim), que à época Alvim utilizava como assinatura do em seu perfil do Twitter (Alvim 2019). A expressão latina remete ao grito de guerra do papa Urbano II, ao declarar a primeira Cruzada em 1095, e vêm sendo associada contemporaneamente a grupos ultra-conservadores alinhados com uma perspectiva de extrema-direita (Rudnitzki; Oliveira 2019).

Nesse contexto de proselitismo ufanista ao nacionalismo e ao cristianismo, acima de tudo emerge a figura de Bolsonaro, numa estratégia de culto à personalidade (Khrushchev 2007), característica do autoritarismo. Mas, independente do próprio conteúdo da fala do protagonista, a trilha sonora de fundo dá importantes pistas sobre a ideologia subjacente. Afinal, Richard Wagner, compositor alemão assumidamente antissemita, teve suas composições amplamente utilizadas em peças de propaganda e comunicados oficiais durante o regime nazista. Lohengrin, ópera escolhida como trilha sonora por Alvim, era também uma das composições preferidas de Adolf Hitler (Martins, 2020). Nesse cenário, Alvim faz um discurso que alude ao Ministro da Propaganda da Alemanha nazista, Joseph Goebells.

Consideramos que o contexto apontado extrapola a "coincidência retórica" no que diz respeito às similaridades com o discurso nazista, justificativa utilizada por Alvim (G1 Política 2020). E, embora o governo federal tenha tradado o fato como caso isolado, tendo sido o secretário exonerado no dia seguinte à publicação do vídeo, é importante lembrar que tal fato encontra precedentes que, à luz de acontecimento tão explícito, devem ser considerados. Afinal, o secretário em questão foi nomeado por um presidente que tem um histórico de declarações ofensivas contra negros (Affonso; Macedo 2017), índios (Exame, 2020), mulheres (Grego 2017) e homossexuais (El País 2018), para citar alguns exemplos complementares aos que já foram apresentados.

O próprio slogan da campanha de Bolsonaro, Brasil acima de tudo, Deus acima de todos, supostamente apropriado em homenagem à Brigada de Infantaria Paraquedista do Exército (Gazeta 2018), precisa ser colocado em perspectiva, observando seu cunho fascista (Putti 2019), Ao se referir ao ufanismo nacionalista e cristão, notamos uma reverberação dos mesmos valores exibidos simbolicamente no vídeo de Alvim. Se colocado em relação ao nazismo, soma-se ainda o fato de que Brasil acima de todos remete à Deutschland über alles (Alemanha acima de todos), primeira frase do hino alemão, exaltada durante o regime nazista, e evitada durante o período de desnazificação que sucedeu a Segunda Guerra Mundial.

No plano discursivo, o pronunciamento de Alvim evoca o surgimento de uma nova classe artística, caracterizada pela exaltação do nacionalismo. Ele diz: “A arte brasileira da próxima década será heroica e será nacional. Será dotada de grande capacidade de 
envolvimento emocional e será igualmente imperativa, posto que profundamente vinculada às aspirações urgentes do nosso povo, ou então não será nada” (BBC 2020). Essa frase, é uma adaptação do discurso de Goebbels transcrito em sua biografia ao se referir às estratégias de padronização estética para a Alemanha idealizada por Hitler (idem). Nesse sentido, lembramos que, conforme apontado em Arquitetura da Destruição (1992), uma das referências sobre a ascensão e consolidação do nazismo, é que este se trata, acima de tudo, de um projeto estético. Por isso, torna-se imprescindível submeter uma suposta arte degenerada ao escárnio e à repulsa, enquanto uma visão unilateral e totalitária do que seria o belo - e, portanto, cabível às artes - imposta.

Argumentamos que essa criação deliberada de uma estética específica para um governo tem relação direta com os conceitos de economia do sinal e mimese, abordados nos próximos tópicos, a partir de um referencial teórico selecionado por duas lógicas distintas, mas que se complementam: a primeira é a genealogia intelectual à qual nos filiamos, composta por pensadores que orbitavam tanto os Internationalen Kornhaus-Seminare (Seminários Internacionais do Celeiro), promovidos por Harry Pross, quanto os corredores da Freie Universität Berlin (Universidade Livre de Berlim) na década de 1980; além disso, compreendemos a pertinência de abordar o tema por uma perspectiva que relaciona objetos comunicacionais com um olhar antropológico motivos pelos quais Christoph Wulf, Vicente Romano e Harry Pross constituem a espinha dorsal teórica do presente trabalho.

\section{O SIMULACRO DOS MEDIA E A ECONOMIA DO SINAL}

Cientista político e jornalista, Harry Pross (1997) elaborou o conceito de economia do sinal ao refletir especificamente sobre a relação entre mídia e poder. Para o autor, todo o desenvolvimento tecnológico midiático visa reduzir o esforço de emissão do sinal. Num primeiro momento, dependíamos apenas dos recursos propiciados pelo nosso corpo, tais como a nossa voz e nossos gestos, nomeado pelo autor de mídia primária. Por conta disso, as emissões de mensagens careciam de alcance no espaço e no tempo. Posteriormente, desenvolvemos aparatos para ampliar o alcance (no espaço e/ou no tempo) para nossas emissões (mídia secundária). A escrita (textual e/ou imagética) representa o exemplo mais evidente e corriqueiro da mídia secundária. Por fim, conseguimos tornar o alcance no espaço e no tempo potencialmente infinito com o advento de tecnologias caracterizadas por um jogo de aparatos (um codificador de emissão e um decodificador de recepção, podendo ou não existirem mais aparatos intermediando ambos). A essa mídia, que à época do autor tinha como principais exemplos o rádio e a televisão, é dado o nome de mídia terciária.

Cabe ressaltar que, embora Pross tenha pensado sua teoria da mídia no contexto da comunicação de massa, a dinâmica por ele demonstrada ainda se aplica no contexto da atual comunicação em rede. Isso porque, apesar de todo indivíduo com acesso à internet seja um emissor potencial, as lógicas de circulação de conteúdo (que vão desde as lógicas algorítmicas até as dinâmicas de mercado, passando pelas diferentes 
valorações que os indivíduos fazem às fontes) fazem com que as posições de emissor e receptor ainda se encontrem presentes, na prática. Ilustramos isso ao apontar para a diferença de alcance de postagens de indivíduos desconhecidos com relação às postagens vindas de veículos de informação consolidados, ou mesmo de organizações com interesses no fluxo de determinadas informações, que podem fazer uso tanto de sistemas formais de pagamento para ampliação do alcance (conhecidos, entre outros termos, como links patrocinados), quanto de sistemas não-oficiais inorgânicos (popularmente referidos como robôs) que simulam engajamento ${ }^{2}$ nas postagens, replicando-as ou comentando, com a intenção de apresentar para os algoritmos uma relevância que, factualmente, não existe.

Pross aponta para o fato de que, consoante com a diminuição do esforço de emissão, existe um acúmulo de poder. Pelo menos dois fatores colaboram com isso. O primeiro é de ordem financeira: quanto menor o esforço de emissão, maior o capital necessário para que essa emissão ocorra. De maneira geral, as pessoas podem falar e/ou gesticular sem envolver algum tipo de ônus financeiro. Para imprimir um livro, por exemplo, já existem os custos de diagramação, impressão e distribuição. Para emitir um sinal pela televisão, por sua vez, existe uma série de custos, tanto com equipamentos quanto com licenças, entre outros. Por conta disso, a detenção do capital se refere também a uma capacidade de emissão, não somente de produção, levando ao exercício de poder sobre quem não o detém - o receptor.

O segundo fator de acúmulo de poder para o sinal economicamente emitido é de ordem simbólica (simbólico este utilizado de acordo com a acepção original do termo - syn-ballein - que, em grego, significa aquilo que une). Se a capacidade de emitir para muitos, com esforço reduzido, motivado por razões econômicas, é restrita a poucos, os pontos de vista, os valores, as ideologias, as crenças, os paradigmas, os preconceitos e as falhas desses poucos são recebidos por muitos, dada a extensão do sinal potencialmente infinita no espaço e no tempo. Trata-se então de uma concentração do poder de poucos sobre muitos. Destarte, sem o risco de soar como exagero, é possível aferir que, quanto mais econômicos, mais os meios de comunicação tendem à hegemonia. Tal afirmação toma por base a análise de Johan Huizinga (2017), para quem os meios de comunicação de massa são solo fértil para a proliferação do fascismo, assim como a contundência de Walter Benjamin (1996), para quem a estetização da política, possibilitada pela reprodutibilidade técnica e exacerbada pela comunicação de massa, é prática cotidiana ao fascismo.

A economia do sinal da qual Pross fala prevê uma hiperconcentração de poder por parte de quem emite a mensagem. Ela considera ainda a estrutura funcionalista do processo comunicacional, no qual as funções de emitir e receber são operadas por sujeitos distintos e em processos não concomitantes. Assim, emite de forma econômica aquele que, com menor esforço, atinge o maior número possível de receptores. É o que se pode dizer que acontece com Bolsonaro e sua equipe, por

${ }^{2} \mathrm{O}$ uso do termo engajamento neste trabalho se refere ao léxico corrente das conhecidas redes sociais digitais, não sendo nossa intenção problematizar a questão do termo em aspectos sociais para além do uso corrente do termo. 
exemplo. Com esforço mínimo inclusive em questões técnicas, pois uma outra característica de seus comunicados em vídeo é a falta de produção e o aspecto visual tosco, eles ainda fazem uso das tecnologias de comunicação em rede para que, a partir da emissão, ocorra a retransmissão de suas mensagens. Essa retransmissão acontece tanto por parte de quem apoia o governo, quanto por parte de quem se indigna com a mensagem - sem contar o uso de robôs (Kalil; Santini 2002) -, além dos próprios meios hegemônicos, que noticiam a repercussão dos comunicados originais. Esses processos, no entanto, todos centrados no virtual, desconsideram a centralidade do corpo na comunicação em sua simulação de uma realidade que não se concretiza materialmente. São os estudos acerca da mimese na comunicação, trabalhados no tópico a seguir, que nos permitem entender melhor essa argumentação.

\title{
MIMESE NA COMUNICAÇÃO
}

$\mathrm{Na}$ sociedade contemporânea, os meios de comunicação eletrônicos são considerados, sozinhos, sinônimo da mídia como um todo, fazendo com que hoje seja improvável pensar em mídia sem pensar em internet e nos dispositivos móveis digitais, tais como os smartphones. Na perspectiva de Romano (2004), esse processo, com protagonismo dos meios e conteúdos audiovisuais, gera um desequilíbrio ecológico na comunicação social, levando o ser humano a ignorar os demais sentidos e, com isso, negar algo que é de sua própria natureza.

Assim, há todo um movimento de resgate do corpo como protagonista dos processos de comunicação, conforme o pensamento de Pross (1972 apud Baitello Junior 1998), que o denomina mídia primária - parametrizada pela nossa constituição biológica e características evolutivas. Tal como os demais primatas, nos caracterizamos como seres miméticos, seres que se fundamentam no vínculo com os demais para existência como espécie. Nesse sentido,

\begin{abstract}
Os outros são parte do eu. Por todo lugar existe tal relação, onde alguém age referindo-se a um mundo já existente e construindo ele mesmo um mundo. Por exemplo, quando alguém imita o movimento de um outro, quando alguém age segundo um modelo, quando alguém representa algo e quando alguém expressa uma ideia corporalmente. Trata-se de saber que isto não é simplesmente um ato imitatório. Representação não é uma simples reprodução que segue ponto por ponto uma imagem original, ela é a criação de algo próprio (Gebauer; Wulf 2004, p. 120).
\end{abstract}

Para os autores, ao desenvolver atos miméticos há uma vinculação entre quem imita e quem é imitado, resultando em mudanças em todos as pessoas envolvidas e estruturando, assim, a comunicação humana, suas causas e consequências. Tem-se, no corpo, o protagonista desse processo. No entanto, a vinculação a partir da mimese necessita da concretude do corpo em mídia primária. Aquilo que acontece em mídia terciária, nessa linha de pensamento, se daria em simulacro da realidade (Morin 2002), uma vez que existe um descompasso entre o mundo concreto e o mundo 
representado. E é isso que acontece na nossa interpretação da performance do exsecretário Alvim como um simulacro das comunicações da Alemanha nazista.

Tem-se aqui o paralelo que serve de âncora para a discussão teórica deste artigo. Embora a ideia do nazismo tenha se expressado em um projeto estético visual específico, esse projeto tinha lastro na realidade concreta de uma comunidade, que fisicamente se empenhava em demonstrar sua aquiescência à ideologia dominante. As paradas e os eventos cívicos do partido nazista alemão mobilizavam milhares; as mostras de arte eram muito bem delineadas dentro da estética greco-romana, conhecida a primeira pelo uso de proporções geométricas equilibradas na representação dos corpos e a segunda pela representação imponente desses mesmos corpos. Além disso, filmes e materiais de propaganda impressos traziam a cara do inimigo, o povo judeu e sua (considerada) arte degenerada, assim como negras e negros, pessoas com deficiência e/ou má formação - sem contar nos comportamentos apresentados como desviantes, tal como a homossexualidade. De uma forma abrangente, todas aquelas e aqueles desviantes do padrão dominante desejado.

Esse inimigo, o bode expiatório ou vítima sacrificial da qual fala Girard (1990), muito bem delineado, passou a ser perseguido e sacrificado pelo que se entendia como o bem geral da nação alemã. Trata-se de um movimento reflexo da humanidade; o sacrifício como forma de apaziguar as crises sociais. Se por vezes o sacrificado é aquele com poucos laços com a comunidade, por outras é aquilo que ela tem de mais precioso. Não importa; o ritual do sacrifício é um dos mais mimetizados na cultura humana ainda nos dias de hoje, independente de credos, podendo ser relacionados com aqueles cujos comportamentos são considerados desviantes a partir da obra organizada por Velho (1985). No contexto do fenômeno analisado, com lastro na vida concreta, a ideologia nazista foi então mimetizada na carne, gerando um vínculo fortíssimo entre seus simpatizantes e aqueles que eram considerados os bodes expiatórios, sendo os vínculos de dor ou de ódio (Gebauer; Wulf 2004) tão fortes quanto aqueles de amor.

No contexto contemporâneo, com a vivenciada nova onda de conservadorismo e com os novos regimes totalitários (Demier; Hoelever, 2016; Valencia-García 2020), percebese o forte lastro deixado pelo nazifascismo na sociedade. Sendo um projeto tão vinculador, que ecoa nos dias de hoje, ele convém ao governo brasileiro, que sistematicamente tem feito uso de sua retórica. No entanto, na versão de Goebbels imitada por Alvim, - e por todo o discurso do governo Bolsonaro -, o bode expiatório está em um eterno devir. Embora a linguagem audiovisual reproduzida no nosso objeto de estudo seja a da Alemanha nazista, o discurso não mantém o mesmo lastro com a realidade que o original. Ser contra e querer mudar "tudo isso que está aí", como frequentemente se ouve o presidente dizer, pode representar muita coisa, mas também pode não significar nada. O processo fica muito claro com a exoneração de Alvim, ele próprio um bode expiatório do simulacro montado. $O$ discurso nazifascista, embora tenha permanecido, também é ele descartável. Ao menor sinal de inconveniência, também será queimado. 
Essa é a interpretação possível a partir desse estudo, apontando um contexto no qual o simulacro apresenta um grau de obviedade tão grande que não parece ser capaz de gerar mimese, apenas imitação. Se o vínculo se dá a partir da mimese, e toda a sua complexidade nos processos comunicacionais, ele então não se faz possível em algo que é raso, sem profundidade, nem perspectiva.

\section{ECOLOGIA DA COMUNICAÇÃO COMO UM CONTRAPONTO ÉTICO}

Incapacitados de dialogar com os simulacros, os sujeitos então passam a ser subordinados a eles, haja visto o já discutido descompasso na relação de poder entre emissor e receptor num modelo comunicacional que visa a economia do sinal. Esse modelo, no entanto, já há décadas vem se mostrando ineficiente nos processos de comunicação social. Para além da perspectiva de que a comunicação não é simplesmente um esquema de emissão e recepção, nem mesmo de troca pura e simples, como também se acostumou dizer, tem-se um sistema muito mais complexo, que envolve naturezas distintas, materiais e imateriais, concretas e virtuais, por vezes racionais, por outras nem tanto. Esse sistema, que privilegia uma comunicação menos funcional e mais comunitária, também tem em vista sistemas outros que os hegemônicos ignoram no ato de comunicar. Busca-se, assim, uma forma de equilibrar esses processos.

Podemos assumir que a restituição do equilíbrio de poder entre os envolvidos no processo comunicacional foi o horizonte de Vicente Romano, um ex-orientando de Harry Pross. Romano tem uma trajetória que perpassa a denúncia do papel da educação, da violência e do entretenimento na formação daquilo que ele denomina como mentalidade submissa (Romano 1998). Dentre as estratégias midiáticas apontadas por Romano como responsáveis nesse processo, destacamos a personificação da política e a censura, ambas imediatamente comparáveis com a nomeação de mito, que recebe Bolsonaro, bem como, conforme já demonstrado, o projeto de estética nacionalista e clássica defendida por Alvim (assim como seu então chefe).

Consequentemente à denúncia dos processos de formação da mentalidade submissa, Romano passa a se debruçar sobre as possibilidades de soluções a essa questão em um contexto que prevê uma sociedade harmônica e em comunhão. Em uma de suas últimas obras, Romano (2004) sugere a proposta de uma Ecologia da Comunicação. Isso porque o diagnóstico do autor sobre o contexto midiático atual aponta para um desequilíbrio em pelo menos duas frentes: a primeira diz respeito aos sentidos envolvidos nos processos comunicacionais (privilegia-se a visão e, em menor intensidade, a audição, ambos sentidos de distância, enquanto ausentam-se os estímulos táteis, olfativos e gustativos - sentidos de proximidade); a segunda frente se refere às duas funções comunicacionais - função informativa, privilegiada pelos meios de comunicação de massa, e função social, cujo desenvolvimento é mais tímido nos meios de comunicação contemporâneos. 
Assim, de acordo com Romano, como consequência desse desequilíbrio comunicativo, habitamos em um ambiente midiático que, por favorecer os sentidos de distanciamento, desfavorece as relações humanas. Consoante com o argumento anteriormente exposto neste trabalho, esse ambiente favorece então o simulacro no lugar da mimese, uma vez que o próprio corpo é apagado do processo comunicacional. Nesse contexto, a Ecologia da Comunicação visa observar, em adição aos sentidos de distanciamento, os sentidos de proximidade, assim como inibir a difusão midiática quando esta prevalece ou suplanta a comunicação primária. Por consequência, visa balancear as funções informacional e social da comunicação.

Assumindo os processos miméticos inerentes ao corpo, a busca pela comunicação primária visa ampliar as potencialidades de gregarização dos indivíduos, ou seja, essa característica inerente ao ser humano que é de viver em grupos e, em consequência, em sociedade. Contudo, é necessário apontar uma diferença central entre a comunicação ecológica e os processos de mobilização social tais como os que ocorreram durante o regime nazista: a Ecologia da Comunicação admite também uma dimensão ética. Romano (2004) denominou essa dimensão de ética da solidariedade. Em nossa interpretação, tal ética pode ser sintetizada em dois valores: o equilíbrio e a diversidade. Daí nosso argumento da Ecologia da Comunicação como contraponto democrático ao totalitarismo afim da comunicação econômica: enquanto a comunicação econômica visa a concentração do poder de emissão que culmina num processo de homogeneização, a comunicação ecológica privilegia a diversidade de conteúdos e meios, de maneira que o apagamento da própria distinção entre emissores e receptores é um horizonte necessário. Ignorada tal distinção, ocorreria um esvaziamento na própria relação de poder necessária para a proliferação de ideologias totalitárias.

Cabe dizer que, apesar de reconhecermos que outras dimensões, tais como a desigualdade de classes, poder e cultura mediarem os processos comunicacionais, argumentamos, a partir de Romano (2004), o quanto a própria estrutura comunicacional econômica, se não criadora, tende a ser responsável pela manutenção do totalitarismo. Nesse sentido, à alteração da estrutura comunicacional, corresponde uma alteração da organização social (IUAMA 2020). Dessa forma a reflexão, aplicada ao objeto de estudo em questão, nos faz aferir o quanto um projeto estético pautado em noções clássicas greco-romanas não encontra lastro em uma cultura miscigenada, heterogênea, plural, cambiante, como é a sociedade brasileira. Ao esbarrarmos uns com os outros nos ônibus lotados, nas calçadas acidentadas, no calor semiárido do Nordeste e no frio subtropical do Sul, na vastidão da megalópole ou da Amazônia, algo dentro de nós parece nos dizer que uma estética não é cabível. Mais gritante ainda é quando essa estética está distante 9 mil quilômetros e 2400 anos de nós, como é o caso da Grécia Clássica. É no sentido de apaziguar tal incoerência que a Ecologia da Comunicação emerge como a alternativa para nos voltarmos para uma ética e para a mimese, para além da estética vazia do simulacro. Assim a Ecologia da Comunicação, em diálogo com a perspectiva girardiana anteriormente abordada, ao invés de nomear um bode expiatório para o sacrifício, integra todos os indivíduos de uma sociedade, em uma perspectiva complexa na qual o sacrifício se faz desnecessário, uma vez que o 
desejo mimético se torna disperso a partir do momento em que não está centrado em uma forma de emissão centralizada em poucos sentidos, mas sim de comunhão equilibrada.

\section{CONCLUSÕES}

Este texto parte do pressuposto que os mecanismos comunicacionais contemporâneos, centrados nos meios de comunicação de massa, privilegiam uma espécie de transmissão de mensagens que desfavorece a função social da comunicação. Ao dar espaço a um formato de emissão massiva, que se expande potencialmente com as tecnologias de rede digitais, impactam um público propenso a uma recepção acrítica das mensagens. Observa-se a insurgência de um modelo comunicacional com ares totalitários na sociedade brasileira, potencializado pelas comunicações oficiais do governo federal, sobretudo naquelas emitidas pelo próprio presidente da república e seus imediatos diretos, como ministros e secretários. Esse fenômeno é analisado a partir de um vídeo postado na página oficial da Secretaria Especial da Cultura no Facebook, no qual o então secretário da pasta, Roberto Alvim, utiliza a mesma estética dos comunicados praticados durante a Alemanha nazista. Alvim, que foi exonerado do cargo no dia seguinte à publicação do vídeo, ainda parafraseia Joseph Goebbels, ministro da propaganda de Adolf Hitler.

Se a Alemanha sonhada por Hitler a partir de um ideal visual estético greco-romano continha lastros na sociedade, em um processo no qual o corpo estava sempre em evidência não só nas mensagens como também em manifestações públicas de apoio ao que estava sendo pregado, aquilo que repete Bolsonaro e seus aliados, em especial o ex-secretário Alvim, foco deste estudo, está longe de carregar esse mesmo lastro. Prometendo sempre o sacrifício do bode expiatório como forma de apaziguar a crise dos sentidos, a própria instituição não consegue se decidir pelo bode expiatório da vez, sendo "contra tudo isso que está aí" até o momento que ser contra é conveniente, assim como a favor. Nesse sentido, a própria demissão de Alvim foi um expurgo ideal para o simulacro construído. Superficial e desvinculado como somente o próprio simulacro é.

Percebe-se, enfim, a necessidade de repensar esse sistema, de forma que a comunicação seja uma ferramenta de exercício democrático, com vistas em uma sociedade justa, equilibrada e centrada em seus valores coletivos e sociais. Essa busca encontra eco naquilo que Vicente Romano (2004) apresentou como Ecologia da Comunicação. Um sistema que considera a comunicação muito mais em seu caráter social que informacional e que, conforme Arruda Rocco e Miklos (2018, p. 14), é resistente por natureza, uma vez que contradiz os sistemas econômico e político hegemônicos para os quais "[...] é interessante que sejamos monotemáticos, unilaterais, maniqueístas e unidimensionais", que culminam na manutenção das perspectivas vigentes, sob a égide de "governos murífices, plutarquias predatórias, fundamentalismos intolerantes e oligopólios midiáticos" (luama; Miklos 2019, p. 51). Nesse sentido, contra a repetição simulada de uma história, busca-se uma vivência 
renovada de experiências, respeitando as características individuais de cada elemento, porém centrada na sociedade como um todo.

\section{REFERÊNCIAS}

AFFONSO, Julia; MACEDO, Fausto, 2017. Justiça condena Bolsonaro por "quilombolas não servem nem para procriar". Estadão [em linha]. 3 outubro 2017. [Acesso em 31 janeiro 2020]. Disponível em: https://bit.ly/2GGW5Uq.

ALVIM, Roberto. Twitter: @RobertoAlvim4 [em linha]. 2019. [Acesso em 20 janeiro 2020]. Disponível em: https://bit.ly/37bcdcw.

ARQUITETURA da Destruição, 1992. Direção de Peter Cohen. Alemanha: Universal.

ARRUDA ROCCO, Agnes de Sousa; MIKLOS, Jorge, 2018. Ecologia da comunicação: desafios para a concepção de uma comunicação social cidadã. Paulus: Revista de Comunicação da FAPCOM [em linha]. 2018. v. 2, n. 3. [Acesso em 18 fevereiro 2020]. Disponível em: https://bit.ly/2SV7FkF.

BAITELLO JUNIOR. Norval, 1998. Comunicação, Mídia e Cultura. São Paulo em Perspectiva [em linha]. 1998. V. 12, nº 04, Comunicação e Informação. [Acesso em 31 janeiro 2020]. Disponível em: https://bit.ly/2RLGtWo.

BAITELLO JUNIOR, Norval, 1999. O animal que parou os relógios: ensaios sobre comunicação, cultura e mídia. São Paulo: Annablume.

BARRETO, Marcelo Menna, 2019. Suzano: discurso de ódio incentiva violência. Extraclasse [em linha], 13 mar. 2019. [Acesso em 31 janeiro 2020]. Disponível em: https://bit.ly/397BwNt.

BBC News Brasil, 2020. Após referência a Goebbels, secretário de Cultura Roberto Alvim diz que semelhança com discurso nazista foi 'coincidência retórica' [em linha]. 17 janeiro 2020. [Acesso em 2 fevereiro 2021]; Disponível em: https://cutt.ly/ZkdBCl2.

BENJAMIN, Walter, 1996. A obra de arte na era de sua reprodutibilidade técnica. Em: BENJAMIN, Walter. Magia e técnica, arte e política. São Paulo: Brasiliense.

BOBBIO, Norberto; MATTEUCCI, Nicola; PASQUINO, Gianfranco, 1998. Ideologia. Dicionário de Política. 11. Ed. Vol. 1. Brasília: UNB.

COPLE, Júlia, 2019. 'Passar fome no Brasil é uma grande mentira', diz Bolsonaro. $O$ Globo [em linha]. 19 julho 2019. [Acesso em 31 janeiro 2020]. Disponível em: https://glo.bo/2S5b3ZU.

CRUZ, Isabela, 2020. Quais são as queixas contra Bolsonaro no Tribunal de Haia. Nexo [em linha]. 27 julho 2020. [Acesso em 29 julho 2020]. Disponível em: https://bit.ly/3hQvvJl.

DEMIER, Felipe; HOEVELER, Rejane. (orgs.), 2016. A onda conservadora: ensaios sobre os atuais tempos sombrios no Brasil. Rio de Janeiro: Mauad X. 
DUARTE, Jorge; FONSECA JUNIOR, Wilson Corrêa, 2003. Relacionamento fonte/jornalista. Em: DUARTE, Jorge. Assessoria de imprensa e relacionamento com a mídia: teoria e técnica. 2. Ed. São Paulo: Atlas.

DUARTE, Marcia Yukiko Matsuuchi, 2010. Estudo de caso. Em: DUARTE Jorge; BARROS, Antonio (orgs.). Métodos e técnicas de pesquisa em comunicação. 2. ed. São Paulo: Atlas.

EL PAÍS, 2018. O que Bolsonaro já disse de fato sobre mulheres, negros e gays [em linha]. 7 outubro 2018. [Acesso em 31 janeiro 2021]. Disponível em: https://bit.ly/2RMd3qY.

EXAME, 2020. "Cada vez mais, o índio é um ser humano igual nós”, diz Bolsonaro [em linha]. 24 janeiro 2020. [Acesso em 31 janeiro 2020]. Disponível em: https://bit.ly/2uRW9yh.

FOLHA DE S.Paulo, 2019. Bolsonaro cancela assinaturas da Folha no governo federal e ameaça anunciantes do jornal [em linha]. 31 outubro 2019. [Acesso em 31 janeiro 2020]. Disponível em: https://bit.ly/36QtB5C.

FOLHA DE S.Paulo, 2020. Em vídeo, Alvim copia Goebbels e provoca onda de repúdio nas redes sociais [em linha]. 17 janeiro 2020. [Acesso em 31 janeiro 2020]. Disponível em: https://bit.ly/2OeFwDA.

FONSECA, Nathalia, 2019. Declarações chocantes marcam mandato de Bolsonaro. Último Segundo [em linha]. 07 agosto 2019. [Acesso em 31 janeiro 2020]. Disponível em: https://bit.ly/31foulo.

G1 Brasília, 2019. Bolsonaro sugere 'fazer cocô dia sim, dia não' para reduzir poluição ambiental" [em linha]. 09 agosto 2019. [Acesso em 31 janeiro 2020]. Disponível em: https://glo.bo/37NUtEC.

G1 Política, 2020. "Coincidência retórica", diz secretário de Cultura sobre discurso semelhante ao de ministro de Hitler [em linha]. 17 janeiro 2020. [Acesso em 31 janeiro 2020]. Disponível em: https://glo.bo/31fKBRt.

GAZETA do povo, 2018. 'Brasil acima de tudo': conheça a origem do slogan de Bolsonaro [em linha]. 24 outubro 2018. [Acesso em 31 janeiro 2020]. Disponível em: https://bit.ly/2tIMm34.

GEBAUER, Gunter; WULF, Christoph, 2004. Mimese na cultura: agir social, rituais e jogos, produções estéticas. São Paulo: Annnablume.

GIRARD, René, 1990. A violência e o sagrado. São Paulo: Editora UNESP.

GREGO, Mauricio, 2017. Piada de Bolsonaro sobre sua filha gera revolta nas redes sociais. Exame [em linha]. 18 setembro 2017. [Acesso em 31 janeiro 2020]. Disponível em: https://bit.ly/37lxsCO.

HUIZINGA, Johan, 2017. Nas sombras do amanhã: um diagnóstico da enfermidade espiritual de nosso tempo. Goiânia: Caminhos.

IUAMA, Tadeu Rodrigues, MIKLOS, Jorge, 2019. Da economia dos sinais para a ecologia da comunicação: O imaginário como possível catalisador para uma mudança 
de perspectiva. Revista Internacional de Folkcomunicação [em linha]. 2019, v. 17, n. 39. [Acesso em 18 fevereiro 2020]. Disponível em: https://bit.ly/3bNwyHv.

IUAMA, Tadeu Rodrigues, 2020. Ludocomunicação: Um Contraponto CríticoPropositivo à Gamification, observado a partir da participação em larps. Tese (Doutorado em Comunicação) [em linha] - Universidade Paulista, São Paulo. [Acesso em 31 mar. 2021]. Disponível em: https://cutt.ly/JcuCMaG.

KALIL, Isabela, SANTINI, R. Marie, 2020. Coronavírus, Pandemia, Infodemia e Política. Relatório de pesquisa [em linha]. 01 de abril de 2020. São Paulo / Rio de Janeiro: FESPSP / UFRJ. [Acesso em 20 mai. 2020]. Disponível em: https://cutt.ly/NyUIQ7W.

KHRUSHCHEV, Nikita, 2007. The cult of the individual. The Guardian [em linha]. 26 abril 2007. [Acesso em 20 janeiro 2020]. Disponível em: https://bit.ly/2RNo7mH.

MAIA, Gustavo, 2019. Para repórter da Globo, apoiadores de Bolsonaro gritam WhatsApp e Facebook. UOL Brasília [em linha]. 01 janeiro 2019. [Acesso em 31 janeiro 2020]. Disponível em: https://bit.ly/31bxUqM.

MARTINS, Sérgio, 2020. Música de Wagner usada em vídeo de Alvim era a favorita de Hitler. Veja [em linha], 17 janeiro 2020. [Acesso em 31 janeiro 2020]. Disponível em: https://bit.ly/2RKXmQF.

MELLO, Patrícia Campos, 2019. Whatsapp admite envio maciço ilegal de mensagens nas eleições de 2018. Folha de S.Paulo. 8 outubro 2019. [Acesso em 31 janeiro 2020]. Disponível em: https://bit.ly/2GFwRpN.

MENEZES, José Eugenio de Oliveira, 2016. Cultura do ouvir e ecologia da comunicação [em linha]. São Paulo: UNI. [Acesso em 14 fev. 2021]. Disponível em:

https://cutt.ly/ykV9BHN.

MORIN, Edgar, 2002. Cultura de massas no século XX. Vol I: Neurose. 9 ed. Rio de Janeiro: Forense Universitária.

NALON, Tai; CUNHA, Ana Rita; LIBÓRIO, Bárbara, 2019. Em dez semanas como presidente, Bolsonaro deu uma declaração errada por dia. Aos Fatos [em linha] 11 março 2019. [Acesso em 31 janeiro 2020]. Disponível em: https://bit.ly/38VoaDB.

NIKKLAS, Jan; GUIMARÃES, Thayz, 2020. Roberto Alvim é demitido da Secretaria Especial da Cultura. O Globo [em linha]. 17 janeiro 2020. [Acesso em 31 janeiro 2020]. Disponível em: https://glo.bo/2OgnGQu.

OLIVEIRA, Felipe, 2021. Fala de Bolsonaro pró-vacina reduziu tuítes contra imunização, diz estudo. Tilt [em linha]. 9 fevereiro 2021. [Acesso em 14 fevereiro 2021]. Disponível em: https://cutt.ly/MkVXo8C.

PAINS, Clarissa, 2019. 'Menino veste azul e menina veste rosa', diz Damares Alves em vídeo. O Globo [em linha]. 03 janeiro 2019. [Acesso em 31 janeiro 2020]. Disponível em: https://glo.bo/31iWbLB.

PROSS, Harry, 1997. A economia dos sinais e a política [em linha]. Texto de apresentação do Seminário "A Explosão da Informação", ocorrido de 26 a 28 de agosto de 1997, no auditório Sesc Paulista. [Acesso em 31 janeiro 2020]. Disponível em: https://bit.ly/37MDwu8. 
PUTTI, Alexandre, 2019. "Deus acima de todos é expressão fascista que esconde sede de poder”. Carta Capital [em linha]. 30 outubro 2019. [Acesso em 31 janeiro 2020]. Disponível em: https://bit.ly/36MyRqw.

ROMANO, Vicente, 1998. La formación de la mentalidad sumisa. Madri: Endymion.

ROMANO, Vicente, 2004. Ecología de la comunicación. Hondarribia: Editorial Hiru.

RUDNITZKI, Ethel; OLIVEIRA, Rafael, 2019. Deus vult: uma velha expressão na boca da extrema direita. Revista IHU On-line [em linha]. 3 maio 2019. [Acesso em 2 fevereiro 2021]. Disponível: https://cutt.ly/8kdCDmw.

SECRETÁRIO da Cultura, 2020. Roberto Alvim cita ministro nazista em pronunciamento [em linha]. Brasília, 17 janeiro 2020. [Acesso em 20 janeiro 2020]. Disponível em: https://bit.ly/38hNG5Q.

UOL Política, 2021. Bolsonaro rebate gasto com leite condensado com xingamento à imprensa [em linha]. 27 janeiro 2021. [Acesso em 2 fevereiro 2021]. Disponível em: https://cutt.ly/okdKoKI.

VALENCIA-GARCÍA, Louie Dean (Ed.), 2020. Far-Right Revisionism and the End of History: Alt-Histories. London: Routledge.

VELHO, Gilberto (Org.), 1985. Desvio e divergência: uma crítica à patologia social. 5. ed. Rio de Janeiro: Jorge Zahar. 